\title{
Faktor-faktor yang mempengaruhi tingginya Keterwakilan perempuan pada pemerintahan Desa Tambun Arang
}

\author{
Mardiana Mardiana ${ }^{1 *}$, Miranti Miranti ${ }^{2}$, Siti Maryam $^{3}$ \\ ${ }^{123}$ Fakultas Ilmu Sosial dan Ilmu Politik, Universitas Muara Bungo \\ *Korespondensi Penulis
}

\section{Informasi Artikel Abstrak}

Kata Kunci :
Perempuan
Pemerintahan Desa
Keterwakilan

Histori Artikel :
Perempuan memiliki peran vital di dalam kehidupan. Untuk menghadapi perkembangan jaman, di era ke-21 ini perempuan juga tak kalah dengan kaum laki-laki. Pada pemerintahan pun perempuan banyak yang menduduki jabatan. Penelitian ini bertujuan untuk menganalisis factorfaktor yang mempengaruhi tingginya keterwakilan perempuan pada pemerintahan Desa Tambun Arang. Penelitian ini merupakan penelitian deskriptif kualitatif. Hasil penelitian menunjukkan bahwa faktor-faktor yang mempengaruhi tingginya keterwakilan perempuan dalam pemerintahan Desa Tambun Arang adalah ketokohan dalam masyarakat dan kekuatan untuk menyerap aspirasi perempuan. Program yang telah dilakukan untuk perempuan di Desa Tambun Arang diantaranya yaitu Senam Tebo, Peralatan Prasmanan, Kursus menjahit dan Memasak, Pertemuan mingguan dan yasinan.

Copyright (C) 2019 Jurnal Politik dan Pemerintahan Daerah 


\section{Pendahuluan}

Secara realitas politik kaum perempuan masih sangat kurang. Kendala utama disebabkan oleh laki-laki dan perempuan dalam memandang dan memperlakukan perempuan. Budaya patriarkhi di kalangan masyarakat mengakar dan mendominasi dalam kehidupan, bahkan dalam lingkungan terkecil seperti keluarga, nuansa dominasi laki-laki sangat kuat, terlebih di pedesaan. Label dan cap yang diberikan pada sosok perempuan sangat kental sebagai orang lemah, tidak bermanfaat dan terbelenggu ketergantungan telah di doktrin secara turun temurun. Perempuan dipersepsikan sebagai orang kelas dua yang seharusnya di rumah dan dininabobokkan dengan konsumerisme, hidonisme dalam cengkeraman kapitalisme. Perempuan lemah tidak sepatutnya bergelut dengan dunia politik yang penuh dengan kekerasan dan kekasaran permainan kekuasaan. Perempuan dinilai tidak mampu memimpin dan membuat kebijakan karena patron membentuk perempuan sangat tendensius mengutamakan perasaan sehingga jauh dari sikap rasionalitas.

Persepsi negative tersebut dilekatkan pada perempuan sendiri telah terstruktur sedemikian rupa dibenak kaum perempuan dan kaum laki-laki. Pembongkaran budaya patriarkhal men-jugment perempuan membuat mitos sangat luar biasa kuat. Pemberdayaan perempuan terbentur dinding sangat kokoh dari interpretasi perempuan terhadap tinjauan politik, agama, sosial. Perempuan.

Sebenarnya mempunyai otonomi mutlak tentang dirinya. Sebagai manusia mempunyai kedudukan setara membawa kepemimpinan di muka bumi. Perempuan memiliki hak dan kewajiban yang sama sebagai warga negara dalam mengatur kesejahteraan manusia. Telah terjadi kesenjangan antara gagasan keadilan yang mendudukkan perempuan dengan laki-laki setara, namun realitas terjadi perempuan masih terkungkung oleh tidak adanya ruang kesempatan memadai mengaktualisasikan perannya.

Perempuan bekerja bukanlah merupakan suatu hal yang tabu untuk dilakukan. Keterlibatan perempuan dalam dunia kerja tidak serta merta mengindikasikan bahwa perempuan bekerja hanya untuk mencari nafkah dan mengejar karir. Ada sebab-sebab lain yang membuat perempuan ingin bekerja, khususnya bekerja di organisasi birokrasi. Makna kerja yang paling mendasar selalu dikaitkan dengan kebutuhan ekonomi, seperti: pemenuhan kebutuhan makanan, tempat tinggal, baik untuk individu dan masyarakat, meskipun demikian ditemukan juga adanya makna kerja lain yang lebih bersifat subjektif yang ditawarkan dari suatu pekerjaan seperti prestasi, kehormatan, kontak social.

Dalam dunia kerja di bidang birokrasi pemerintahan, memang telah terdapat peraturan dan kebijakan yang mengedepankan akan kesetaraan gender sehingga kecil kemungkinan untuk menemukan ketidaksetaraan gender dalam peraturan dan kebijakan tersebut. Tetapi, masih terdapat hal-hal lain yang membatasi wanita untuk dapat berada pada titik yang tinggi di dalam sebuah jabatan. Terkadang, untuk mendapatkan sebuah posisi yang tinggi diperlukan kinerja yang lebih daripada biasanya, contohnya seperti harus lembur, melakukan perjalanan dinas ke luar kota, dan lain sebagainya. Sedangkan, wanita memiliki prioritas yang lain selain bekerja dan mencari nafkah, yaitu mengurusi keluarga. Maka, seringkali kita temukan bahwa di sebuah organisasi yang bergerak di bidang birokrasi pemerintahan pun terjadi bias gender.Kesetaran gender selalu menjadi momok setiap pesta pemilukada. Desa Tambun Arang yang terletak di Kabupaten Tebo yang membentuk kepengurusan Oraganisasi Desa dengan mayoritas Perempuan.

Perempuan adalah agen perubahan menuju kehidupan yang lebih berkualitas. Oleh sebab itu sangat penting bagi perempuan untuk duduk dalam posisi-posisi penting di wilayah kebijakan publik. Dalam jumlah yang sedikit, suara perempuan tidak akan memiliki kesempatan untuk membawa perubahan yang berarti dalam proses pengambilan keputusan politik. Untuk itu dengan banyaknya perempuan di pengurusan Desa harus dimanfaatkan dengan sebaik-baiknya untuk mendorong adanya pembaharuan dan perbaikan situasi terutama sekali Program yang telah Dirancang Oleh Kepala Desa Tambun Arang. Pemerintah Desa Tambun Arang program yang dirancang untuk pemebrdayaan perempuan. Program yang dilakukan untuk pemberdayaan perempuan pemerintah Desa Tambun Arang menganggarkan. Dari uraian latar belakang penulis tertarik untuk melakukan penelitian dan di tulis kedalan sebuah karya ilmiah atau skripsi yang berjudul Faktor-Faktor Yang Mempengaruhi Tingginya Keterwakilan Perempuan Di Perngkat Desa Tambun Arang (Studi Kasus Desa Tambun Arang Kabupaten Tebo) 


\section{Metode}

Adapun metode yang penulis gunakan dalam penelitian ini adalah metode kualitatif yang bersifat deskriptif. Menurut Sugiono, metode penelitian kualitatif adalah metode penelitian yang digunakan untuk meneliti pada kondisi obyek alamiah, dimana peneliti adalah sebagai instrument kunci, teknik pengumpulan data dilakukan secara trianggulasi (gabungan), analisis data bersifat induktif, dan hasi penelitian kualitatif lebih menekankan makna daripada generalisasi. Penelitian yang bersifat deskriptif bertujuan untuk pemecahan masalah pada masa sekarang, penelitian deskriptif tidak terbatas hanya sampai pada pengumpulan dan penyusunan data, tetapi meliputi analisa dan interprestasi tentang hasil data. Penelitian deskriptif membandingkan persamaan dan perbedaan fenomena tertentu lalu mengambil bentuk studi komperatif, atau mengukur suatu dimensi seperti dalam berbagai bentuk studi kuantitatif.

\subsection{Jenis Data.}

Data yang diperoleh dari penelitian ini, terdiri atas data primer dan data sekunder. Kedua jenis data saling mendukung untuk memperkuat hasil penelitian. Adapun pengertiannya masing-masing:

a. Data Primer.

Data primer adalah data yang diperoleh dari lokasi penelitian dan merupakan hasil observasi serta wawancara dengan bagian yang terkait dalam pengumpulan data penelitian. Data ini masih murni dan belum di olah dalam suatu proses tertentu.

b.Data Sekunder.

Data sekunder adalah data yang diperoleh dalam bentuk yang sistematis, sudah diolah dan dipublikasikan. Data ini dapat berbentuk buku-buku, laporan-laporan dan bahan dokumen yang menyangkut masalah Peranan dan Politik Kesetaraan Gender.

\subsection{Teknik Pengumpulan Data.}

Dalam penelitian yang perlu diperhatikan adalah teknik dalam pengumpulan data. Teknik pengumpulan data adalah alat-alat pengumpulan data yang tersusun baik serta disesuaikan dengan tujuan penelitian. Teknik pengumpulan data yang dipergunakan dalan penelitian ini yaitu :

1. Studi Kepustakaan (Library Research)

Yaitu suatu teknik untuk mendapatkan data yang bersifat pijakan teoritis dalam penelitian. Studi ini berguna untuk memperoleh pendapat para ahli dengan mempelajari bahanbahan kepustakaan atau literatur berupa peraturan perundang-undangan yang isi atau materinya berkaitan dengan masalah yang akan dibahas serta buku-buku yang berhubungan dengan masalah yang akan diteliti. Studi Kepustakaan pada dasarnya merupakan langkah awal yang menentukan dalam setiap kegiatan penelitian. Dalam melakukan studi pustaka, peneliti memperoleh data dari:

1. Perpustakaan Universitas Muara Bungo;

2. Perpustakaan Daerah Kabupaten Bungo; dan

3. Literatur, Jurnal, Mass Media Cetak dan sumber berita on line.

2. Studi Lapangan (Field Research)

Yaitu dengan cara memperoleh data yang bersifat primer atau langsung didapatkan dari lokasi penelitian. Untuk mendapatkan data melalui studi lapangan maka dalam penelitian ini menggunakan 2 (dua) metode:

a. Metode Observasi (Pengamatan)

Yaitu studi yang disengaja dan sistematis tentang fenomena-fenomena sosial dan gejala psikis dengan jalan pengamatan serta pencatatan. Pengamatan adalah salah satu alat pengumpulan data yang dilakukan dengan cara mengamati dan mencatat secara sistematik gejala-gejala yang diselidiki. Pengamatan akan menjadi alat pengumpulan data yang baik, apabila : 
1. Mengabdi kepada tujuan penelitian;

2. Direncanakan secara sistematik;

3. Dicatat dan dihubungkan dengan komposisi-komposisi yang umum; dan

4. Dapat dicek dan dikontrol validitas, reliabilitas dan ketelitiannya.

\section{b. Metode Wawancara}

Wawancara adalah proses tanya jawab dalam penelitian yang berlangsung secara lisan dimana dua orang atau lebih bertatap muka dengan mendengarkan secara langsung informasiinformasi atau keterangan-keterangan yang biasanya didasarkan pada pengumpulan informasi bagi keperluan penelitian. Jenis wawancara yang dilakukan adalah wawancara bebas yang disebut juga wawancara tidak terpimpin, yaitu proses wawancara dimana interviewer tidak secara sengaja mengarahkan tanya-jawab pada pokok-pokok persoalan dari fokus penelitian dan orang yang diwawancarai.

\subsection{Teknik Pemilihan Informan.}

Purposive sampling adalah teknik pengambilan sampel sumber data dengan pertimbangan tertentu. Pertimbangan tertentu ini, minsalnya orang tersebut yang dianggap paling tahu tentang apa yang kita haraapkan, atau mungkin dia sebagai pengusaha sehingga akan memudahkan peneliti menjajahi objek dan situasi sosial yang diteliti. Dengan demikian pemilihan imforman tidak berdasarkan kuantitas, tetapi kualitas dari informan terhadap masalah yang akan diteliti. Dalam pelaksanaan di lapangan guna mengumpul data, pemilihan informan dapat berkembang sesuai dengan kebutuhan dan kemantapan peneliti didalam memperoleh data. Jadi yang menjadi kepedulian bagi peneliti kualitatif adalah tuntasnya perolehan informasi dengan keragaman variasi yang ada, bukan hanya sampel sumber data.

\subsection{Analisis Data.}

Hal yang sangat penting dalam penelitian adalah menganalisis data karena hal ini dapat memberikan arti dan makna dalam suatu penelitian.Dalam penelitian ini data yang dikumpulkan melalui studi pustaka, studi lapangan yang diperoleh dari hasil observasi ditempat penelitian dengan melalui wawancara pada responden, adapun tahapan analisis data dalam penelitian ini adalah :

a. Mengumpulkan data yang berhubungan dengan penelitian;

b. Melakukan pemeriksaan data yang didapat, apakah telah sesuai dengan yang diharapkan;

c. Pengelompokkan data-data untuk menjawab pertanyaan terhadap suatu penelitian;

d. Melaksanakan Pembahasan dan perumusan tehadap data yang didapat;

e. Mengambil kesimpulan akhir terhadap data yang diteliti.

Data yang diperoleh dari penelitian akan penulis analisis dalam bentuk kualitatif, sehingga mendapatkan gambaran umum secara deskriptif atas permasalahan yang dibahas.

\section{Hasil dan Pembahasan}

Pemerintah merupakan kemudi dalam bahasa latin asalnya Gubernaculum. Pemerintah ada$\underline{\text { lah }}$ organisasi yang memiliki kewenangan untuk membuat kebijakan dalam bentuk ( penerapan hukum dan undang-undang) di kawasan tertentu. Kawasan tersebut adalah wilayah yang berada di bawah kekuasaan mereka. Pemerintah berbeda dengan pemerintahan.

Pemerintah merupakan organ atau alat pelengkap jika dilihat dalam arti sempit pemerintah hanyalah lembaga eksekutif saja. Sedangkan arti pemerintahan dalam arti luas adalah semua mencakup aparatur negara yang meliputi semua organ-organ, badan atau lembaga, alat kelengkapan negara yang menjalankan berbagai aktivitas untuk mencapai tujuan negara. Lembaga negara yang dimaksud adalah lembaga eksekutif, legislatif, dan yudikatif. Tambun Arang adalah salah satu desa yang terletak di kecamtan Muara Tabir Kabupaten Tebo, memiliki pemerintah desa yang mayoritas adalah perempuan. Faktor yang mempengaruhi tingginya tingkat kererwakilan perempuan di pemerintahan desa Tambun Arang sebagai berikut: 


\section{Ketokohan dalam masyarakat.}

Ketokohan adalah orang yang memiliki kredibilitas, daya tarik, dan kekuasaan. Aristoteles, menyebutnya sebagai ethos. Dengan kata lain, ketokohan sama dengan ethos, yaitu gabungan antara kredibilitas, atraksi dan kekuasaan. Orang yang memiliki ketokohan menurut Nimmo dapat disebut juga sebagai pahlawan politik. Desa Tambun Arang Kecamtan Muara Tabir Kabupaten Tebo. Memiliki pemerintahan atau pengurus desa yang mana pengurusnya mayoritas adalah perempuan. Sebagaimana wawancara penulis dengan BPD desa Tambun Arang.

"Pengurus Desa TAmbun Arang pada tahun ini atau pemerintahan yang sekarang mayoritas adalah perempuan. Yang mana kepala desanya Perempuan, Sekdesnya, Kaurnya. Ya untuk pemerintahan yang sekarang pengrusnya mayoritas perempuan”.

Ketua lembaga Adat Desa Tambun Arang Juga membenarkan yang mana beliau mengatakan: "Pemimpin kalau dalam agama ya memang harus laki-laki didahulukan. Namun kalu laki-laki tidak sanggup barulah perempuan. Begitulah yang terjadi di desa Tambun Arang. Dikarenakan laki-laki tidak sanggup menjalankan amanah yam au tidak mau perempuan yang harus memimpin. Di desa Tambun Arang ini mayoritas adalah perempuan karena untuk sekarang ini mereka masih memegang janji untuk menjalankan tugas sebaik-baiknya”.

Dari wawancara penulis dapat kita analisa pemerintah yang baik adalah pemerintah yang menjalankan amanah dan janjinya dengan sebaik mungkin untuk menepati janji tersebut. Sebagaimana pada pemerintahan desa Tambun Arang yang mayoritas adalah perempuan. Perempuan yang menjadi pengurus desa Tambun Arang tersebut mampu menjalani tugasnya dengan baik. Tugas yang diemban di pundaknya adalah amanah yang diberikan oleh masyarakat kepada pengurus desa Tambun Arang. Ketokohan yang menyebabkan sehingga pengurus desa Tambun Arang mayoritas perempuan. Sebagaimana wawancara penulis terhadap Ketua Pemuda Tambun Arang, apa penyebab pengurus Desa Tambun Arang ini mayoritas adalah perempuan;

"Penyebab kenapa pengurus desa kami sebagian besar adalah perempuan ini disebabkan karna untuk kaum laki-laki ini tidak bisa menjalankan amanah dengan baik, sering menjalankan tugas tidak jujur atau yang terjadi pada pemerintahan sebelumnya adanya indikasi korupsi. Inilah yang menyebabkan orang atau masyarkat menjadi tidak percaya terhadap kepemimpinan kepala desa yang sebelumnya”.

Dari wawancara ini ketua pemuda Tambun arang dapat kita simak dalam menjalankan tugas pemerintah kita harus menjalankan dengan sebaik-baik mungkin. Jangan sampai kita membuat masyarakat menjadi risih terhadap kepemimpinan kita.

\section{Kekuatan untuk menyerap aspirasi perempuan.}

Kekuatan, yaitu suatu kemampuan kondisi fisik manusia yang diperlukan dalam peningkatan prestasi belajar gerak. Kekuatan merupakan salah satu unsur kondisi fisik yangsangat penting dalam berolahraga karena dapat membantu meningkatkan komponen-komponenseperti kecepatan, kelincahan dan ketepatan. Namun kekuatan disini adalah kemampuan untuk menyerap atau menerima aspirasi masyrakat desa Tambun Arang. Apasaja kebutuhan atau keluhan yang terjadi di Desa Tambun Arang. Sebagaimana wawancara penulis dengan Sekretaris Desa Tambun arang;

"Pemerintah Desa Tambun Arang insyaallah akan menjalankan pemerintahan ini dengan baik. Apa saja yang menjadi keluhan masyarakat kami yang bersifat umum bukan untuk pribadi insyaalah kami laksanakan dengan baik. Banyak yang menjadi keluhan masyarakat kami terutama sekala adalah ibu-ibu. Yang mana selama ini peralatan untuk membuat acara besar tidak ada seperti peralatan prasmanan. Walaupun kecil tapi bermanfaat untuk ibu-ibu. Itu yang tidak diperhatikan oleh pengurus desa yang lain. Dan masih banyak lagi yang lainnya yang kami lakukan untuk kepentingan orang banya". 
Dari wawancara penulis diatas pemerintah Desa Tambun Arang akan berusha untuk memperhatikan masyarakat dan mengabulkan apa yang menjadi keinginan atau keluhan masyarakat. Hal senada juga dikatakan oleh Tokoh Masyarakat Desa Tambun Arang mengatakan;

"Pengurus Desa TAmbun Arang yang sekarang menurut penilaian kami sangat mengerti tentang keadaan masyarakat. Ini menurut kami karena mereka rata-rata adalah perempuan. Hati perempuan yang benar baik dia langsung terbuka hatinya melihat keluhan masyarakat. Mereka akan cepat merespon sesuatu hal yang terjadi dengan masyarakat itulah uniknya perempuan. Perempuan hatinya sangat lembut dan mudah tersentuh melihat keadaan masyarakatnya yang tidak mampu".

Dari wawancara penulis kepada ibu sekretaris Desa (Sekdes) dapat kita ambil kesimpulan aspirasi dari masyarakat perlu kita perhatikan untuk kesejahteraan masyarakat salami menjadi pemimpin.

\subsection{Perempuan Lebih Amanah.}

Amânah yang artinya jujur atau dapat dipercaya. Secara bahasa, amânah (amanah) dapat diartikan sesuatu yang dipercayakan atau kepercayaan. Amanah juga berarti titipan (al-wadî‘ah). Amanah adalah lawan dari khianat. Amnah terjadi di atas ketaatan, ibadah, al-wadî’ah (titipan), dan ats-tsiqah (kepercayaan).

Dengan demikian, sikap amanah dapat berlangsung dalam lapangan yang sangat luas. Oleh karena itu, sikap amanah merupakan sesuatu yang dipercayakan untuk dijaga, dilindungi, dan dilaksanakan. Pemerintahan Desa Tambun Arang yang mayoritas perempuan ini adalah pemerintahan yang amanah. Sebagaimana wawancara penulis dengan Tokoh masyrakat Tambun Arang, menurut ibu bagaimana pemerintahan Desa Tambun Arang yang sekarang masyoritas perempuan ini:

"Pemerintah Tambun Arang atau pengusrus Desa kami ini adalah orang yang mengayomi masyarakat. Memperhatikan masyarakat apasaja keluhan masyarakat Desa Tambun Arang ini. Misalnya masyarakat mengeluhkan infrastrukutur (jalan setapak) pemerintah desa sekarang langsung di tanggapi. Keuangan desa memeang dimanfaatkan jujur daan terbuka tentang keuangan".

Dari wawancara penulis diatas pemerintah Desa Tambun Arang sekarang bisa mengayomi masyarakat serta memperhatikan kebutuhan masyarakat umum. Hal yang sama juga di sampaikan oleh ketua Pemuda Desa Tambun Arang mengatakan:

"Pemerintah sekarang walaupun perempuan mereka mengerti keluhan masyarkat. Dan mereka langsung bersikap apa yang harus dilakukan. Walaupun sesuatu itu kecil. Salah satu contoh peralatan prasmanan itukan masalah kecil. Namun pemerintah desa merespon tentang hal itu. Pemerintah Desa langsung mengadakan peralatan tersebut. Hal yang kecil itu sangat diperlukan masyarakat. Yang biasanya peralatan prasmanan menyewa ke desa lain sekarang sudah ada di desa sendiri jadi satu persatu permasalahan terselasaikan”.

Dari wawancara penulis diatas dapat kita ambil kesimpulan pemerintah Tambun Arang yang sekarang bagi informan yang kami waancara merasa pemerintah yang sekarang sudah bagus sudah merespon apa keluhan dari masyarakat dan mengayomi masyarakat Desa Tambun Arang

\section{Program yang telah dilakukan untuk perempuan di Desa Tambun Arang.}

Program kerja adalah susunan daftar kegiatan yang dirancang untuk di laksanakan dalam satu periode kepengurusan. Program kerja ini akan menjadi tolak ukur pencapaian kinerja kepengurusan. Adapun pertanggung jawaban program kerja biasanya dilakukan pada masa akhir kepengurusan dengan format laporan pertanggung jawaban kepada seluruh anggota institusi. Program kerja disini adalah program untuk memberdayakan perempuan untuk lebih baik lagi. Program pemberdayaan untuk perempuan yang dilakukan oleh pemerintah Desa Tambun Arang sebagaiberikut; 


\subsection{Senam Tebo Sehat}

Kegiatan senam Tebo sehat ini adalah salah satu program yang dibuat oleh pemerintah Desa Tambun Arang. Karena kegiatan ini dilombakan setiap tahunnya oleh pemerintah Kabupaten Tebo. Untuk memperkenalkan desa Tambun Arang di Kabupaten Tebo pemerintah Desa berupaya melatih khusus kaum ibu-ibu untuk mengikuti kegiatan senam tebo yang dilakukan di desa TAmbun Arang. Dari hasil kegiatan tersebut pemerintah desa TAmbun Arang mengirim peserta dari desa untuk mengikuti lomba senam tersebut di tingkat KAbupaten Tebo sebagaimana wawancara penulis dengan tokoh masyarakat Tambun Arang. Apa tujuan dari kegiatan senam tebo yang dialakukan ibu-ibu di desa TAmbun Arang ini:

"Dari kegiatan senam Tebo sehat yang kami lakukan ini adalah bertujuan untuk mengisi kegiatan para ibu yang ada di desa Tambun Arang. Selama ini kegiatan inni tidak ada. Khusus kami ibu-ibu paling kegiatan kami ya mengurus rumah tangga atau anak-anak kami. Namun dipemerintahan yang sekarang ini kegiatan para ibu-ibu sudah mulai diperhatikan”.

Dari wawancara penulis diatas pemerintah Desa membuat kegiatan khusus kaum perempuan adalah senam Tebo sehat dan mengiktui perlombaan setiap tahunnya di Kabupaten Tebo. Pemerintah desa Tambun Arang kasi pelayanan juga mengatakan bahwa :

"Program Senam sehat ini dilakukan untuk mengisi kegiatan ibu-ibu. Jadi para ibu-ibu bukan hanya didaapur saja para ibu juga bisa mengisi kegiatan diluar seperti senam. Tujuan dari senam nantinya kalau bisa kita mengikuti lomba senam tebo yang dilakukan oleh pemerintah tebo setiap tahunnya".

Dari wawancara penulis program yang dibuat oleh pemerintah desa ini bertujuan mengisi kegiatan para ibu-ibu selain dari mengurusi rumah tangga.

\subsection{Peralatan Prasmanan}

Peralatan prasmanan ini bertujuan untuk melengkapi kebutuhan ibu-ibu untuk membuat kegiatan atau hajatan. Karena alat prasmanan ini juga mahal harganya jadi bagi ibu-ibu atau keluarga yang tidak mampu bisa meminjam alat prasmanan yang ada di kantor desa. Sebagaimana wawancara penulis dengan Kasi Kesejahteraan Desa Tambun Arang, apa tujuan dari diadakannya peralatan rumah tangga atau prasmanan yang ada di kantor desa ini:

"Peralatan prasmanan yang dibelikan oleh pemerintah desa ini bertujuan untuk memudahkan ibu-ibu apabila melakukan hajatan tidak usah repot-repot lagi keluar desa untuk meminjam prasman. Karena pemerintah desa sudah mengadakan alat tersebut"

Dari wawancara penulis diatas Pemerintah Kabupaten Tebo mebeli perlengkapan rumah tangga untuk kebutuhan ibu-ibu yang akan membuat acara yaitu alat prasmanan. Hal senada juga disampaikan oleh tokoh masyarakat Tambun Arang mengatakan:

"Dengan adanya peralatan prasmanan yang di sudah dibelikan oleh pemerintah desa ini sangat membantu kami. Apalagi pada waktu kami lagi acara. Terkadang kami sempat berpikir bagaimana kami mau buat acara besar besaran mau mengundang orang-orang. Peralatan untuk menyambut tamu tidak ada. Untuk lah pemerintah desa merespon hal tersebut mengerti keluhan masyarakat. Mereka membeli alat-alat yang dibutuhkan masyarakat banyak".

Dari wawancara penulis diatas pemerintah desa TAmbun Arang mengadakan alat prasmana tersebut bertujuan untuk memudahkan masyarakat yang membuat hajatan tidak meminjam atau menyewa keluar dari desa Tambun Arang lagi. 


\subsection{Kursus menjahit dan Memasak}

Pelatihan ini dilakukan bukan hanya kaum perempuan saja namun bagi masyarakat yang mau mengikuti kursus menjahit ini. Kegitan ini bertujuan untuk melatih keterampialan masyarakat Tambun Arang. Supaya masyarakat mempunyai keahlian di bidang menjahit ini. Sebagaimana wawancara penulis dengan Kasi Kesejahteraan Desa Tambun Arang mengatakan:

"kegiatan kursus menjahit ini bertujuan supaya masyrakat mempunyai keahlian didalam menjahit. Jadi apabila masyarakat ataupun mereka pribadi yang mau menjahit pakaian tidak lagi keluar desa tambun Arang ini. Karena masyrakat di desa sudah ada yang bisa menjahit pakain. Dan juga bisa membantu perekonomian keluarga hendaknya”.

Juga dibenarkan oleh tokoh masyarakat mengatakan:

"Ya dari adanya kursus yang dilakukan di balai desa TAmbuna Arang ini setidaknya kami tidak lagi pergi ke desa lain untuk hanya menjahit pakaian kami. Hendak nya masyarakat mau menekuni pekerjaan menjahit ini untuk menopang perekonomian keluarga".

Dari wawancara diatas dapat kita simpulkan kegiatan menjahit yang dilakukan oleh pemerintah desa ini adalah memberdayakan para masyarakat supaya mempunyai keterampilan dalam menjahit sehingga bisa menbantu ekonomi keluarga.

\subsection{Pertemuan mingguan dan yasinan}

Pertemuan mingguan ini bertujuan untuk mempererat hubungan antra masyarakat dengan pemerintah desa, mempererat hubungan antara masyarakat dengan masyarakat. Untuk menjaga tali silaturrahmi dengan masyarakat maupun sesama masyarakat. Sebagaimana wawancara penulis dengan Sekretaris Desa mengatakan;

"kegiatan pertemuan mingguan atau yasinan ini dilakukan setiap hari jum'at. Yang mana tujuannya adalah kami bermaksud menjaga hubungan baik dengan masyarakat kami ini. Maupun menjaga silaturrahmi sesama masyarakat"

Dari wawancara penulis diatas untuk menjaga kekompakan kau perempuan pemerintah Desa TAmbun Arang mengadakan pertemuan mingguan yang dikemas menjagi pengajian mingguan. Hal senada juga disampaikan tokoh masyarakat Desa Tambun Arang menagtakan :

’Pertemuan yang diadakan setiap minggu ini sangat bagus di buat dan diikuti setiap saat oleh Ibu Kepala Desa kami. Jadi bagi ibu-ibu ataupun masyarakat yang mau menyampaikan sesuatu bisa melalui kegiatan tersebut. Yaitu pertemuan mingguan atau yasinan dengan masyarakat".

wawancara penulis dengan Tokoh Masyarakat dari kegitan pertemuan mingguan ini dilakukan berapa kali dalam seminggu;

"pertemuan yang kami lakukan atau yasinan ini kami lakukan setiap satu kali dalam satu minggu, namun kemarin ada juga usulan dari masyarakat agar kegiatan ini dilakukan satu kali dalam satu bualan. Namun masyarakat masyoritas memilih satu kali dalam seminggu"

Wawancara penulis dengan tokoh masyarakat, apa tujuan lain dari kegiatan yasinan ini :

"Selain pertemuan atau silaturrahmi didalam kegiatan yasinan ini kami juga mendoakan arwah orang tua, keluarga atau orang yang telah mendahului kita. Dan juga mendoakan agar masyarakat Tambun Arang di ber kedamaian".

Dari wawancara diatas kegiatan yasinan bukan hanya yasinan saja atau pertemuan saja namun didalamnya juga ada kegiatan lain yang dianggap penting seperti mendo'akan orang kita yang telah meninggalkan kita atau yang lainnya. Wawancara penulis dengan Lemabaga Adat Desa Tambun Arang mengatakan: 


\begin{abstract}
"Kegiatan pertemuan setiap minggu yang dikemas menjadi kegiatan yasinan ini sangat bagus bagi masyarakat kita. Pada pemerintahan sebelumnya memang sudah ada juga yasinan, namun pemerintah sebelumnya tidak mengikuti jadi tidak tahu apa yang menjadi keluhan masyarakat setemput. Sebenarnya pemeintah ini adalah menagyomi masyarakat itulah yang dilakukan oleh pemerintah tersebut. Kami sebagai lembaga adat sangat mendukung kegiatan ini”.
\end{abstract}

Dari wawancara penulis diatas pengajian mingguan yang dilakukan pemerinah Desa TAmbun Arang sangat disenangi oleh masyarakat Tambun Arang. Hal senada juga disampaikan oleh ketua Pemuda Desa TAmbun Arang mengatakan:

"Pemerintah yang baik mengerti keadaan dan keluhan masyarakat kami walaupun hal tersebut kecil. Hal kecil inilah yang menjadi besar. Karena kenapa hal kecil ini kalau lama-lama tidak diselasaikan akan menjadi besar. Pemerintah sekarang ini untuk mengetahui keluhan masyarakat mereka mengadakan pertemuan minggiun atau yasinan jadi mereka tahu perkembangan pekerjaan mereka setiap minggunya dan mereka mencari solusinya".

Dari wawancara penulis deatas dapat kiata mabil sebuah kesimpulan bahwa didalam menjalankan amanah masyarakat kita harus atau setidaknya mengetahui apa yang menjadi keluhan dari masyarakat kita. Bagaimana cara kita mengetahui keluhan demi keluhan yang dialami masyarakat kita. Disini kita memikirkan apa yang harus dilakukan, pemerintah Desa Tambun Arang mencaari atau menanyakan keluhan masyarakat yaitu melalui kegiatan pertemuan yang diakadakan setiap minggunya.

\title{
Kesimpulan
}

Dari penelitian yang penulis lakukan dapat diambil kesimpulan sebagai berikut: Faktor-faktor yang mempengaruhi tingginya keterwakilan perempuan dalam pemerintahan Desa Tambun Arang yaitu : Pertama ketokohan dalam masyarakat adalah orang yang memiliki kredibilitas, daya tarik, dan kekuasaan, kedua kekuatan untuk menyerap aspirasi perempuan. Dan program yang telah dilakukan untuk perempuan di Desa Tambun Arang yaitu ; pertama Senam Tebo Sehat kegiatan senam Tebo Sehat ini adalah salah satu program yang dibuat oleh pemerintah Desa Tambun Arang, kedua Peralatan Prasmanan Peralatan prasmanan ini bertujuan untuk melengkapi kebutuhan ibu-ibu untuk membuat kegiatan atau hajatan, ketiga Kursus menjahit dan Memasak pelatihan ini dilakukan bukan hanya kaum perempuan saja namun bagi masyarakat yang mau mengikuti kursus menjahit ini, keempat pertemuan mingguan dan yasinan pertemuan mingguan ini bertujuan untuk mempererat hubungan antra masyarakat dengan pemerintah desa, mempererat hubungan antara masyarakat dengan masyarakat. 


\section{Daftar Pustaka}

\section{Sumber Buku - buku:}

[1] Aida Vitayola, 2008, Feminim dan pemberdayaan perempuan, Bandung, Pustaka hidayah

[2] Hendra Nurtjohjo,2005, filsafat demokrasi. Bumi Aksara, Jakarta.

[3] Halim,Abd. 2014. Politik Lokal. LP2B. Sleman Yogyakarta

[4] Jhon M. Echolas dan Hassan shadaly, 1992, Kamus Inggris Indonesia (Jakarta: Granmedia, Cek. Ke XX.

[5] Marijan, Kancung. 2006. Demokrasi Di Daerah, Pelajaran Dari Pilkada Secara Langsung, Pustaka Eureka, Surabaya.

[6] Miranti, 2015, Perempuan dan politik local, Yogyakarta:GRE PUBLISHING..

[7] Nursil, adman. 2004. Political Marketing; Strategi Memenangkan Pemilu Sebuah Pendekatan Baru Kampanye DPR,DPD, Presiden. Gramedia, Jakarta

[8] Silalahi Ulber. 2009. Metode Penelitian Sosial. Pt Refika Aditama : Bandung

[9] Schroder, Peter 2004. Strategi Politik (Politische Strategien). Refika Aditama, Bandung

[10] Sugiono. 2012. Metode penelitian kuantitatif kualitatif dan R\&D.Alfabeta : Bandung

[11] Peter Schroder, 2004, Pt Refika Aditama : Bandung

[12] Victory dalam Nasarudin Umar, 1992, Argumen Kesetaraan Gender, Jakarta Paramadina.

[13] Widjaja HAW. 2010. Otonomi Desa. Pt Rajagrafindo Persada : Jakarta

\section{Sumber Peraturan Perundang-Undangan :}

[1] Undang-Undang Republik Indonesia Nomor 32 Tahun 2004 Tentang Otonomi Daerah

\section{Internet :}

[1] http://blogmerko.blogspot.com/2013/05/makalah-pengertian-dan-prinsip-demokrasi.

[2] http://www.definisimu.blogspot.com,diakses

[3] http://www.wri.or.id/tentang-kami/28-filosofi-wri/19-perempuan-dan-kancah-tatapemerintahan\#.Wog2eLM0nIU 